\title{
Monocarboxylate transporter 8 expression in the human placenta: the effects of severe intrauterine growth restriction
}

\author{
S-Y Chan, J A Franklyn ${ }^{1}$, H N Pemberton, J N Bulmer ${ }^{3}$, \\ T J Visser ${ }^{2}$, C J McCabe ${ }^{1}$ and M D Kilby
}

Department of Fetal Medicine, Division of Reproductive \& Child Health, University of Birmingham, Edgbaston, Birmingham B15 2TG, UK

${ }^{1}$ Division of Medical Sciences, Medical School, University of Birmingham, Edgbaston, Birmingham B15 2TT, UK

${ }^{2}$ Department of Internal Medicine, Erasmus University Medical Centre, 3015 GE, Rotterdam, The Netherlands

${ }^{3}$ School of Clinical and Laboratory Sciences, University of Newcastle upon Tyne, Newcastle upon Tyne NE1 4 LP, UK

(Requests for offprints should be addressed to M D Kilby; Email: m.d.kilby@bham.ac.uk)

\begin{abstract}
Thyroid hormones (THs) are essential for normal fetal development, with even mild perturbation in maternal thyroid status in early pregnancy being associated with neurodevelopmental delay in children. Transplacental transfer of maternal THs is critical, with increasing evidence suggesting a role for 3,3',5-tri-iodothyronine (T3) in development and function of the placenta itself, as well as in development of the central nervous and other organ systems. Intrauterine growth restriction (IUGR) is associated with fetal hypothyroxinaemia, a factor that may contribute to neurodevelopmental delay. The recent description of monocarboxylate transporter 8 (MCT8) as a powerful and specific $\mathrm{TH}$ membrane transporter, and the association of MCT8 mutations with profound neurodevelopmental delay, led us to explore MCT8 expression in placenta. We describe the expression of MCT8 in normal human placenta throughout gestation, and in normal third-trimester placenta compared with that associated with IUGR using quantitative reverse transcriptase PCR. MCT8 mRNA was detected in placenta
\end{abstract}

from early first trimester, with a significant increase with advancing gestation $(P=0 \cdot 007)$. In the early third trimester, MCT8 mRNA was increased in IUGR placenta compared with normal samples matched for gestational age $(P<0 \cdot 05)$, but there was no difference between IUGR and normal placenta in the late third trimester. Western immunoblotting findings in IUGR and normal placentae were in accord with mRNA data. MCT8 immunostaining was demonstrated in villous cytotrophoblast and syncytiotrophoblast as well as extravillous trophoblast cells from the first trimester onwards with increasingly widespread immunoreactivity seen with advancing gestation. In conclusion, expression of MCT8 in placenta from early gestation is compatible with an important role in $\mathrm{TH}$ transport during fetal development and a specific role in placental development. Altered expression in placenta associated with IUGR may reflect a compensatory mechanism attempting to increase T3 uptake by trophoblast cells. Journal of Endocrinology (2006) 189, 465-471

\section{Introduction}

Thyroid hormones (THs) are essential for the normal growth and development of the fetus with even minor perturbations in maternal thyroid status during early pregnancy being associated with neurodevelopmental abnormalities in children in later life (Haddow et al. 1999, Pop et al. 1999, Chan \& Kilby 2000, Kilby 2003, Pop et al. 2003). Since effects of maternal thyroid status impact on outcome at a time before development of the thyroid in the fetus, it is clear that supply of maternal THs across the placenta is critical to normal fetal development during pregnancy. Significant transport of maternal THs across the placenta is also evidenced by the finding of significant concentrations of serum thyroxine (T4) and 3,3',5-tri-iodothyronine (T3) in neonates with congenital hypothyroidism and absent endogenous thyroid function (Vulsma et al. 1989).

Babies born with intrauterine growth restriction (IUGR) are major contributors to perinatal and neonatal mortality and up to $10 \%$ display neurodevelopmental delay (Gaffney et al. 1994). Thyroid status is one of several factors believed to play a role in this morbidity, especially in development and function of the central nervous system and placenta (Kilby 2003). We and others have used cordocentesis to perform fetal blood sampling in babies affected by severe IUGR and have reported a statistically significant reduction in circulating concentrations of free T4 and free T3 (Thorpe-Beeston et al. 1991, Kilby et al. 1998). Furthermore, the areas of the 
central nervous system affected by IUGR in both human and rodent models are those that express T3-regulated genes (e.g. PCP-2 in the cerebellum) and are affected similarly in terms of histopathological changes by overt thyroid hormone deficiency (Schwartz 1983).

While circulating concentrations of $\mathrm{T} 4$ and $\mathrm{T} 3$ are considered the major determinants of cellular supply of these hormones, it is clear that other factors potentially modulate thyroid hormone action at a tissue level. These include deiodination of the pro-hormone $\mathrm{T} 4$ to the receptor-binding ligand $\mathrm{T} 3$, and the expression of functional thyroid hormone receptor isoforms. The availability of T3 for local receptor binding, and indeed the transplacental passage of maternal THs, is determined in part by the action of three selenocysteine monodeiodinase subtypes (D1, D2 and D3), as well as by sulphotransferases (Koopdonk-Kool et al. 1996, Stanley et al. 2001, Hernandez \& St Germain 2003).

However, much less is known about the mechanisms of entry of THs into thyroid-responsive tissues. It has been considered that passive diffusion represents a major mode of entry into cells (Ekins 1992), although active uptake has been increasingly recognized to play a part (Hennemann et al. 2001, Abe et al. 2002). Interest has again focused on active uptake of THs since the recent description of the novel, specific, highly potent and active thyroid hormone transporter protein monocarboxylate transporter 8 (MCT8; Friesema et al. 2003). Human MCT8 was cloned in 1994 (Lafreniere et al. 1994); the gene is located at $\mathrm{Xq13} 2$ and comprises six exons encoding a protein with 12 putative transmembrane domains.

We hypothesize that MCT8 plays a critical role in the cellular uptake of T4 and T3 by the placenta for both thyroid hormone action within this organ and for transport of THs to the fetus. To define the role of MCT8 in human development we have determined the expression of MCT8 mRNA in human placenta across gestation. We have demonstrated the presence of MCT 8 mRNA by reverse transcriptase (RT)-PCR and protein by Western immunoblotting, and have described the distribution of MCT8 protein in human placenta (both villous and extravillous) by immunohistochemistry. To investigate the relevance of MCT8 to normal and abnormal placental development and function, we have also compared the expression of mRNA encoding MCT8 in placenta of uncomplicated pregnancies and those complicated by early- and late-onset IUGR.

\section{Materials and Methods}

\section{Collection of placental samples}

The study had the approval of the hospital ethics committee (South Birmingham) and the Research and Development Committee of the Birmingham Women's Hospital.
Placental samples were collected either at surgical termination of pregnancy (in accordance with the Polkinghorne Report) or after elective Caesarean sections. Normal placentae from the early third trimester were obtained following emergency Caesarean section for placenta praevia, maternal tumours or prelabour rupture of membranes (with no infection) with a breech presentation. Placental samples were grouped as follows: early first trimester (6-8 weeks gestation; $n=17)$, late first trimester (9-12 weeks gestation; $n=19)$, second trimester (1320 weeks gestation; $n=13)$, early third trimester (28-34 weeks gestation; $n=6)$, and term (37-41 weeks gestation; $n=16$ ). The gestational ages of the pregnancies were determined by ultrasound scan in the first trimester (using crown-rump length) and confirmed post-natally by feet-length/femur-length ratios (Hern 1984).

Ten cases of severe IUGR were diagnosed prospectively using ultrasound, having at least three of the following four characteristics: (i) ultrasound measurement of the fetal abdominal circumference of less than or equal to the third centile for gestation; (ii) abdominal circumference growth velocity of less than 1.5 S.D. over 14 days; (iii) severe oligohydramnios (amniotic fluid index $<10$ th centile for gestation); (iv) absent end-diastolic flow velocity in the umbilical artery Doppler velocity waveform measurements.

These criteria selected a relatively homogenous, but severe, phenotype and all were delivered by Caesarean section under maternal spinal analgesia. The IUGR group was sub-divided into early- and late-gestation groups, six being at 26-32 weeks gestation and four being at 3738 weeks gestation. The placentae from the early IUGR group were compared with placentae from 28-34 weeks gestation with appropriately grown fetuses for gestational age, and the late IUGR group with normal term placenta.

Immediately after delivery, multiple full-thickness placental biopsies were obtained from the central (periumbilical) region, which has previously been demonstrated to be representative of the entire placenta (Bacon et al. 1986). Placental tissue were dissected off the chorionic plate and washed in iced $0.9 \%$ saline solution as previously described (Chan et al. 2003). No membrane was left adherent to the placental samples and these were snap-frozen in liquid nitrogen and stored at $-70{ }^{\circ} \mathrm{C}$ until analysis or fixed in $4 \%$ formaldehyde solution. A representative sample from these formalin-fixed placental samples was taken for examination by immunohistochemistry.

In addition, placental bed biopsies from women following elective pregnancy termination in the first (812 weeks; $n=3)$ and early second trimester (14-15 weeks; $n=5$ ) of pregnancy were obtained transcervically as previously described (Robson et al. 2002). All placental bed biopsies included in the study were selected to include interstitial extravillous trophoblast and 'transformed' decidual and/or myometrial spiral arteries containing endovascular and/or intramural extravillous trophoblast. 


\section{$R N A$ extraction}

Total RNA was extracted from approximately $100 \mathrm{mg}$ tissue after homogenization, utilizing the Sigma Trisol kit: this used a single-step acid guanidinium/phenol/chloroform extraction procedure following the manufacturer's guidelines, as previously described (Chan et al. 2002). RNA was reverse transcribed using avian myeloblastosis virus (AMV) RT (Promega) in a total reaction volume of $20 \mu \mathrm{l}$ with $1 \mu \mathrm{g}$ total RNA, $30 \mathrm{pmol}$ random hexamer primers, $4 \mu \mathrm{l}$ $5 \times$ AMV RT buffer (Promega), $2 \mu \mathrm{l}$ dNTP mix $(200 \mu \mathrm{M}$ each; Boehringer Mannheim), 20 units ribonuclease inhibitor (RNasin; Promega) and 15 units AMV RT (Promega).

\section{Quantitative TaqMan PCR}

Expression of mRNA encoding MCT8 was determined using the ABI PRISM 7700 Sequence Detection System as described previously by our group (Boelaert et al. 2003, 2004, Chan et al. 2003). RT-PCR was carried out in $25 \mu \mathrm{l}$ volumes on 96-well plates in a reaction buffer containing $1 \times$ TaqMan Universal PCR Master Mix, 100-200 nmol TaqMan probe and $900 \mathrm{nmol}$ primers, as described below. All reactions were multiplexed with a pre-optimized mixture of control probe and primers for $18 \mathrm{~S} \mathrm{rRNA}$ (PE Biosystems, Warrington, Cheshire, UK), enabling data to be expressed in relation to an internal reference to allow for differences in RT efficiency. All samples were measured in triplicate.

Primer and probe sequences for MCT8 were as follows: forward primer, 5'-CAA CGC ACT TAC CGC ATC TG-3'; reverse primer, 5'-GTA GCC CCA ATA CAC ACC AAG AG-3'; probe, 5'-TCC ACA TAC TTC ATC AGG TGT ACA TAG GGA ACA AA-3'.

The TaqMan primers yielded amplicons of $150 \mathrm{bp}$. The MCT8 probe was labelled with flurochrome 6-carboxyflurescein (FAM) and the $18 \mathrm{~S}$ probe with fluorphore VIC. Reactions were as follows: $50{ }^{\circ} \mathrm{C}$ for 2 min, $95{ }^{\circ} \mathrm{C}$ for $10 \mathrm{~min}$, followed by 44 cycles of $95^{\circ} \mathrm{C}$ for $15 \mathrm{~s}$ and $60{ }^{\circ} \mathrm{C}$ for $1 \mathrm{~min}$.

As per the manufacturer's guidelines, data were expressed as $C t$ values (the cycle number at which logarithmic PCR plots cross a calculated threshold line) and used to determine $\Delta C t$ values $(\Delta C t=C t$ of the target gene (e.g. MCT8) minus $C t$ of the control housekeeping gene, $18 \mathrm{~S})$ for each sample. Validation studies of the MCT8 TaqMan primers and probe demonstrated parallel changes in $C t$ values for MCT8 and $18 \mathrm{~S}$ across a wide range of specific concentrations of RNA (data not shown). The mean $\Delta C t$ for each experimental group was compared with the mean $\Delta C t$ for the control group $(\Delta \Delta C t)$ and transformed through the equation $2^{-\Delta \Delta C t}$ to calculate the fold change in gene expression.

\section{Western immunoblotting}

Placental proteins were prepared in lysis buffer (100 mmol/1 NaCl, $0 \cdot 1 \%$ Triton $\mathrm{X}-100$ and $50 \mathrm{mmol} / \mathrm{l}$
Tris, $\mathrm{pH} 8 \cdot 3$ ) containing enzyme inhibitors $(1 \mathrm{mmol} / \mathrm{l}$ PMSF, $0.3 \mu \mathrm{mol} / 1$ aprotinin and $0.4 \mathrm{mmol} / \mathrm{l}$ leupeptin), and denatured $\left(2 \mathrm{~min}, 100{ }^{\circ} \mathrm{C}\right)$ in loading buffer. Protein concentration prior to loading was measured by the Bradford assay with BSA as standard. Western-blot analyses were performed as we have described previously (Friesema et al. 2003, Boelaert et al. 2003). Briefly, soluble proteins $(30 \mu \mathrm{g})$ were separated by electrophoresis in $12.5 \%$ SDS/polyacrylamide gels, transferred to PVDF membranes, incubated in 5\% non-fat milk in PBS with $0 \cdot 1 \%$ Tween prior to incubation with a specific, validated rabbit polyclonal MCT8 antibody used at 1:1000 as described previously (Friesema et al. 2003). After washing, blots were incubated with appropriate secondary antibodies conjugated to horseradish peroxidase for $1 \mathrm{~h}$ at room temperature. After further washes, antigenantibody complexes were visualized by the ECL chemiluminescence detection system on Hyperfilm ECL. Actin expression (monoclonal anti- $\beta$-actin clone AC-15 mouse ascites fluid; Sigma-Aldrich; used at 1:10 000) was used to assess protein loading.

\section{Immunohistochemistry}

Formalin-fixed paraffin-embedded sections of representative placental samples and placental bed biopsies were immunostained using an avidin-biotin peroxidase technique (Vectastain Elite; Vector Laboratories, Peterborough, Cambs, UK) as described in detail previously (Barber et al. 2005). All reagents were prepared as per the kit instructions. Briefly, after dewaxing and rehydration the sections were processed in $0.1 \mathrm{~mol} / \mathrm{l}$ sodium citrate buffer $(\mathrm{pH}$ 6.0) in a pressure cooker at 103 $\mathrm{kPa}$ for $60 \mathrm{~s}$ for antigen retrieval. Slides were then incubated with $1.6 \% \mathrm{H}_{2} \mathrm{O}_{2}$ in methanol to block endogenous peroxidase activity. After washing in $0.1 \mathrm{~mol} / \mathrm{l}$ Tris $/ 0.05 \mathrm{~mol} / 1$ saline (pH 7.6; Tris-buffered saline, TBS), the slides were overlain with the supplied blocking serum in TBS for $10 \mathrm{~min}$, before incubation with a validated rabbit polyclonal antibody to MCT8 (1:1000) for $1 \mathrm{~h}$ at room temperature, as reported before (Friesema et al. 2003). For negative controls the primary antibody was replaced by non-immune serum. After three 5-min washes in TBS the sections were incubated with biotinylated secondary antibody for $30 \mathrm{~min}$, followed, after further TBS washes, by addition of the avidin-biotinperoxidase complex. The reaction was developed by incubation in 3,3'-diaminobenzidine (Sigma Chemical Co) for 5-10 min. Sections were lightly counterstained with Mayers haematoxylin, dehydrated, cleared and mounted in synthetic resin.

\section{Statistical analyses}

Data from the quantitative RT-PCR were expressed as $\Delta C t$ values upon which all statistics were performed. 


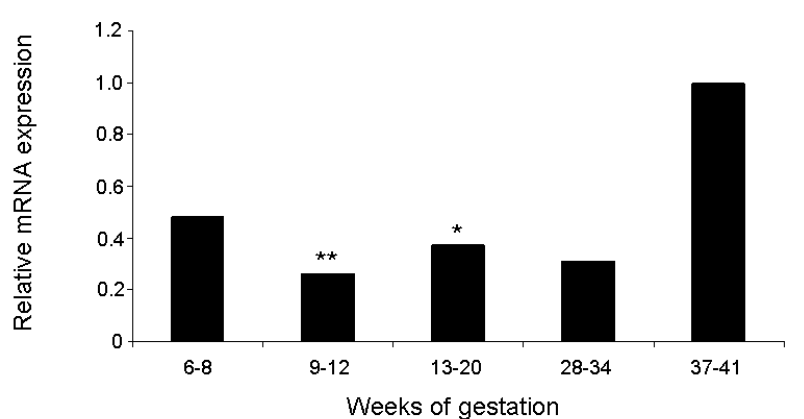

\begin{tabular}{|c|c|c|c|c|c|}
\hline number & 17 & 19 & 13 & 6 & 16 \\
\hline Mean $\Delta \mathrm{CT}$ & 21.7 & 22.6 & 22.1 & 22.3 & 20.6 \\
\pm & \pm & \pm & \pm & \pm & \pm \\
$\mathrm{SE}$ & 0.41 & 0.19 & 0.33 & 1.07 & 0.41 \\
\hline
\end{tabular}

Figure 1 The relative expression of mRNA encoding MCT8 in normal human placenta from 6 to 34 weeks compared with 37-41 weeks (term) gestation, given an arbitrary value of 1 . The number of samples expressing mRNA and the mean \pm S.E. $\Delta C t$ values obtained using quantitative RT-PCR for each group are given in the corresponding columns below the graph; ${ }^{*} P<0.05$; ${ }^{*} * P<0 \cdot 01$.

The means \pm S.E. of $\Delta C t$ values for each group are shown in Figs 1 and 2. Data were analysed using GraphPad software (San Diego, CA, USA). Unpaired two-tailed $t$-test was used for comparison between two groups and ANOVA was used for between-group comparisons of more than two groups with Dunnett's (post-hoc) multiple comparisons test to isolate groups that differed from others. Significance was taken as $P<0 \cdot 05$.

\section{Results}

Expression of $m R N A$ encoding MCT8

mRNA encoding MCT8 was present from the early first trimester and throughout gestation. Quantification of MCT8 mRNA indicated a significant increase with advancing gestation (Fig. 1; ANOVA, $P=0 \cdot 007$ ). With post-hoc testing, a significant reduction in mRNA expression compared with term placenta was evident for placental samples collected at 9-12 weeks gestation $(0 \cdot 26$-fold, $P<0 \cdot 01)$ and at $13-20$ weeks gestation $(0 \cdot 37$-fold, $P<0 \cdot 05)$. However, placenta from the 6-8 and 28-34 weeks gestation groups did not demonstrate statistically significant reductions in MCT8 mRNA expression compared with term placenta. There were also no statistically significant differences between the gestational groups prior to term.

In severe IUGR resulting in delivery in 'early' gestation (26-32 weeks), there was a significant increase of 7.5-fold in the expression of mRNA encoding MCT8 in placenta from IUGR pregnancies compared with gestationally matched placental samples from normal controls $(P<0 \cdot 05)$. However, the difference was no longer statistically

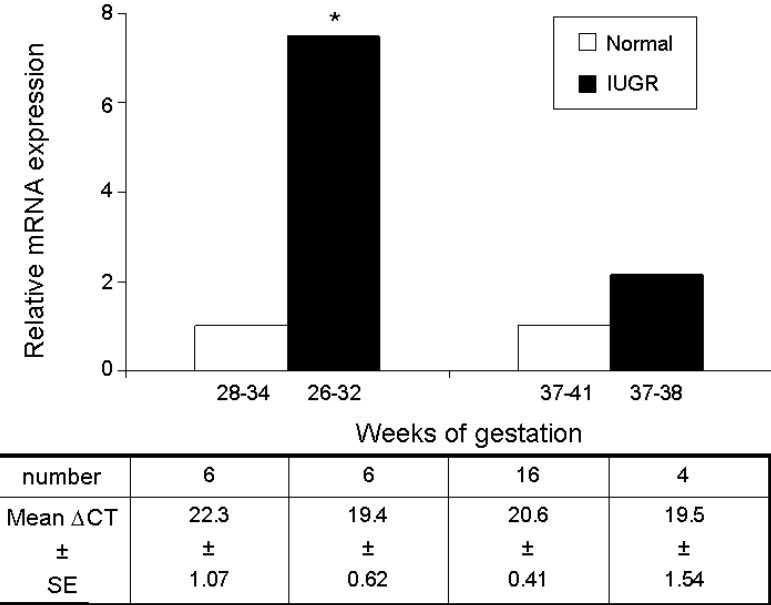

Figure 2 The relative expression of mRNA encoding MCT8 in IUGR human placenta (early and late gestational groups) compared with normal placenta of similar gestational ages, given an arbitrary value of 1 . The number of samples expressing mRNA and the mean \pm S.E. $\Delta C t$ values obtained using quantitative RT-PCR for each group are given in the corresponding columns below the graph; ${ }^{*} P<0 \cdot 05$

significant when comparing 'late' IUGR placenta (3738 weeks gestation) with normal term placenta (Fig. 2).

\section{Western immunoblots}

Protein was extracted from placental homogenates of early (29 weeks) and late (38 weeks) IUGR pregnancy and compared with gestationally matched samples from uncomplicated pregnancies. The MCT8 antibody utilized demonstrated a $50 \mathrm{kDa}$ band on Western immunoblotting, with weaker bands at $63 \mathrm{kDa}$, as previously described in other tissues (Friesema et al. 2003; Fig 3). The early IUGR sample expressed more MCT8 protein than the gestationally matched control while the late IUGR sample showed

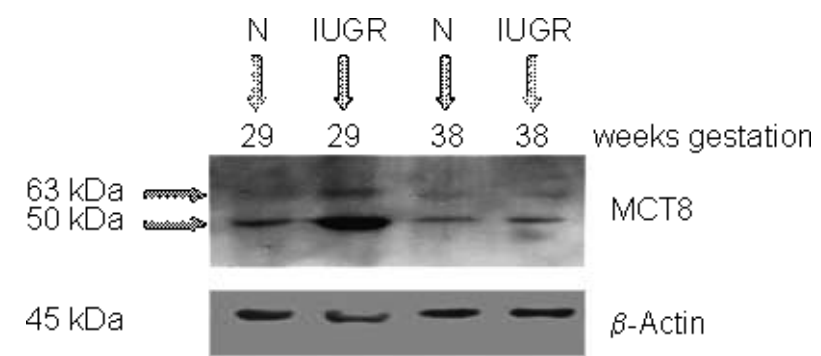

Figure 3 Western immunoblotting showing the presence of the MCT8 protein in extracts of placental homogenates from representative early ( 29 weeks) and late (38 weeks) pregnancies complicated by IUGR compared with gestationally matched normal placenta $(\mathrm{N})$. The antibody utilized demonstrated a $50 \mathrm{kDa}$ band with weaker bands at $63 \mathrm{kDa}$, as previously described in other tissues (Friesema et al. 2003). Immunoblotting for $\beta$-actin on the same blot was used to assess protein loading. 

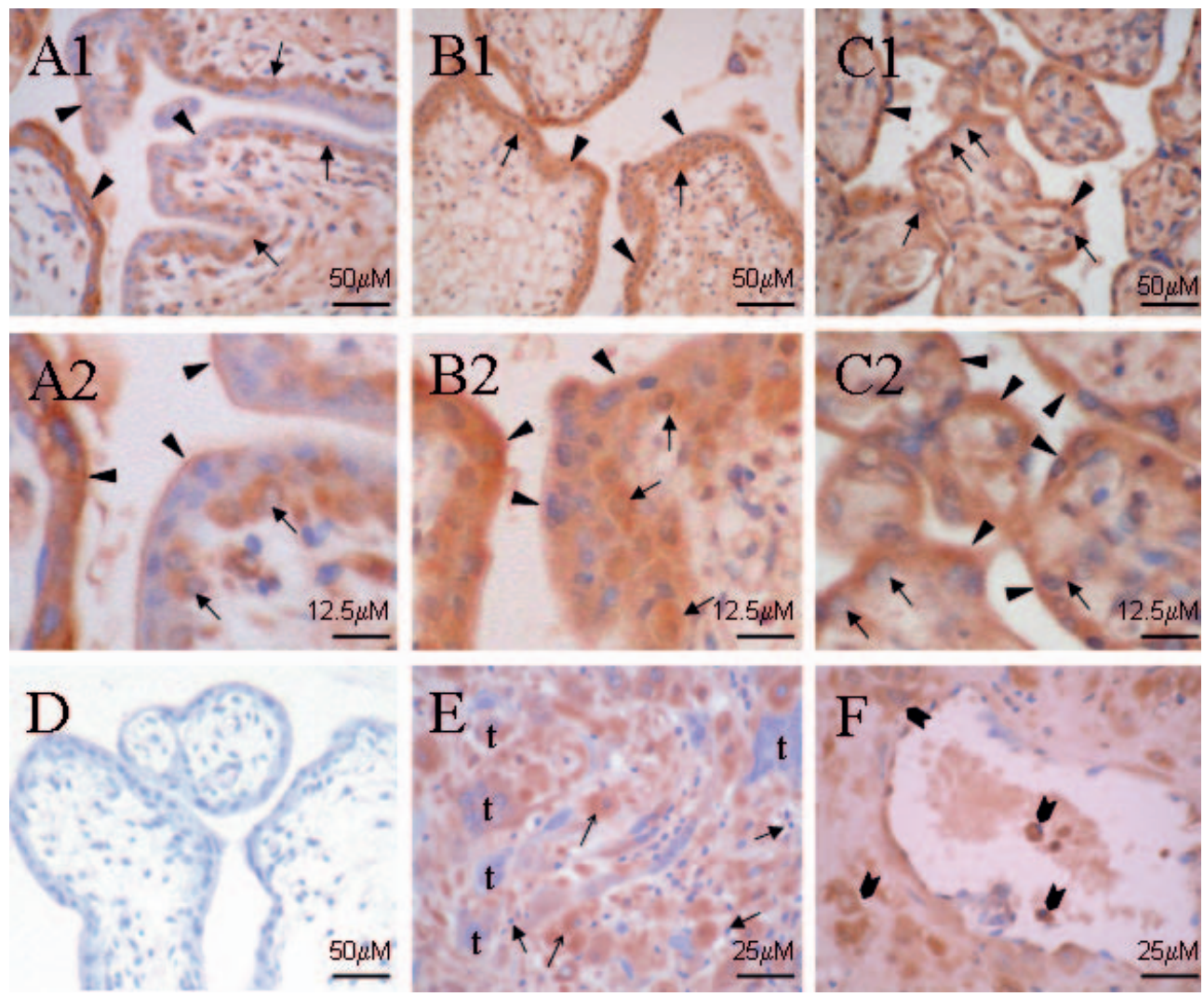

Figure 4 Immunoreactivity for MCT8 in first-trimester (A1 and A2), second-trimester (B1 and B2) and term (C1 and C2) placenta, with a corresponding negative control section from first-trimester placenta treated with non-immune serum (D). (A1) and (A2) In first-trimester placenta there is focal reactivity in villous cytotrophoblast (arrows) and syncytiotrophoblast (arrowheads), with positive villous cytotrophoblast adjacent to negative syncytiotrophoblast. Low immunoreactivity in villous syncytiotrophoblast appears localized preferentially at the surface in contact with maternal circulation. (B1) and (B2) In the second trimester, although still focal, there is more widespread intense immunostaining in both villous cytotrophoblast (arrows) and syncytiotrophoblast (arrowheads). (C1) and (C2) At term there is consistent strong immunoreactivity in syncytiotrophoblast (arrowheads) and in the occasionally present cytotrophoblast (arrows). (E) and (F) Early second-trimester placental bed biopsies showing moderate to strong immunoreactivity in decidual stromal cells (arrows), although decidual lymphocytes (arrows) are negative. Both mononuclear and multinucleate interstitial trophoblasts (t) showed variable reactivity; and (F) endovascular and intramural trophoblast cells (arrowheads) showed strong immunoreactivity. (This figure appears in colour online at http://joe.endocrinology-journals.org/content/vol189/issue3).

no obvious difference compared with control in accord with mRNA data (Fig. 2). Immunoblotting for $\beta$-actin confirmed even protein loading across samples (Fig. 3).

\section{Immunohistochemistry}

Immunohistochemistry was used to localize MCT8 protein in first-, second- and third-trimester placental and placental bed biopsies (Fig. 4). MCT8 was localized to both cytoplasm and nucleus of trophoblast cells. In the first trimester (Fig. 4A1 and A2) there was focal strong reactivity with villous syncytiotrophoblast, with clear positive cells adjacent to negative syncytiotrophoblast. Immunostaining of villous cytotrophoblast was also focal, with intense staining of both cytoplasm and nucleus, often adjacent to negative syncytiotrophoblast. Samples from the early second trimester (14-18 weeks gestation; Fig. 4B1 and B2) showed intense reactivity with villous syncytiotrophoblast and cytotrophoblast, which was again focal, although more widespread than with first-trimester placenta. Again clear positive cells were present adjacent to non-reactive cells of the same type. In normal term placental tissues (Fig. 4C1 and C2) villous syncytiotrophoblast showed consistent strong reactivity for MCT8 with weaker staining of the occasional residual cytotrophoblast cells. At all gestational ages there was weaker reactivity with mesenchymal cells within the villous stroma, including endothelial cells of fetal vessels.

Stromal cells in human decidua from first-trimester pregnancies showed moderate to strong immunostaining 
(Fig. 4E), although there was no reactivity with lymphocytes within the decidual stroma. In second-trimester placental bed biopsies (Fig. 4F) the majority of interstitial trophoblast showed strong staining, although a small proportion of cells remained negative. Where present, endovascular trophoblast was also positive for MCT8 (Fig. 4F).

\section{Discussion}

We have demonstrated that the potent iodothyronine transporter MCT8 is present in the human placenta from early gestation. mRNA encoding MCT8 was evident in normal placenta from 6 weeks gestation, with evidence for increasing expression as gestation advanced. The early presence of MCT8 protein in placenta from the first trimester of pregnancy was also confirmed by immunohistochemistry findings. These results suggest both an early and an increasing role for MCT8 in determining T3 supply to the fetus during ontogeny, as well as a potential role in trophoblast development. Furthermore, significantly higher expression of MCT8 mRNA was evident in placenta affected by severe IUGR, where delivery was required in the early third trimester.

Immunohistochemistry demonstrated that MCT8 protein is expressed in villous trophoblast cells across gestation. In addition, in late first- and second-trimester placental bed biopsies, MCT8 protein was demonstrated in the endovascular extravillous trophoblast. This localization of MCT8 in both villous and extravillous trophoblast is similar to that of thyroid hormone receptor isoform localization described previously (Kilby et al. 1998, Barber et al. 2005). Furthermore, the pattern of localization of MCT8 in focal areas of villous placenta is similar to that of D2 (the enzyme which converts the prohormone, T4, to the active ligand, T3) in the first trimester, as we have previously reported (Chan et al. 2003), with most intense staining in the cytotrophoblast layers and weaker staining in the syncytiotrophoblast. The coordinated expression of MCT8, D2 and thyroid hormone receptors in the relatively undifferentiated villous cytotrophoblast (trophoblast stem cell line) in the first trimester suggests a role for T3 in early placental development. Indeed, T3 has been shown to modulate epidermal growth factor-stimulated changes in first-trimester primary cytotrophoblast proliferation and function in vitro, confirming it to be a T3-responsive tissue (Barber et al. 2005). A role for T3 in modulating uterine invasion by extravillous trophoblast in early pregnancy has also been reported (Laoag-Fernandez et al. 2004), an effect recently shown to be associated with upregulation by $\mathrm{T} 3$ of matrix metalloproteinases (Oki et al. 2004). We have shown that in SGHPL-4 cells (derived by transformation of primary extravillous trophoblasts) T3 interacts with epidermal growth factor to modulate trophoblast proliferation, migration and invasion in vitro (Barber et al. 2005). We postulate that MCT8 expression in trophoblast in the first trimester plays a crucial role in facilitating the T3-regulation of placental development, which would have a bearing on optimal placental function and fetal growth in later gestation.

The recent description (Dumitrescu et al. 2004, Friesema et al. 2004) of association between mutations of the MCT8 gene on the X chromosome and a syndrome of severe neurodevelopmental delay with abnormal circulating thyroid hormone concentrations in boys supports the view that fetal development and function are critically dependent upon an intact MCT8 transporter system within the brain. Their heterozygote mothers do not display an abnormal neurological phenotype, but are characterized by mild perturbation of tests for thyroid function. Since development prior to function of the fetal thyroid is dependent on effective transfer of maternal THs across the placenta it is plausible that alterations in both maternal circulating concentrations of $\mathrm{TH}$ as well as the expression of mutant MCT8 in the maternal uteroplacental bed and the fetoplacental unit, with consequent influences on transport of THs across the placenta, may exacerbate the observed phenotype in affected boys.

A focus of the present study of expression of MCT8 in human placentation is investigation of the effects of severe IUGR. This study has revealed an increase in mRNA encoding MCT8 in human villous placenta affected by severe IUGR requiring preterm delivery when compared with normal placenta. We and others have previously reported that IUGR is associated with relative fetal hypothyroxinaemia (Thorpe-Beeston et al. 1991, Kilby et al. 1998). We have also reported upregulation of thyroid receptor proteins in placenta affected by IUGR and postulated that this may reflect a compensatory mechanism enhancing thyroid hormone action in the hypothyroxinaemic environment of IUGR (Kilby et al. 1998, Kilby 2003). Enhanced expression of MCT8 may represent an additional compensatory mechanism active in the fetoplacental unit attempting to increase T3 uptake in trophoblast cells or to increase the transplacental passage of THs in these compromised pregnancies.

It would be important to establish a functional role for MCT8 within the placenta which could partly be addressed through in vitro studies in primary trophoblast cultures and choriocarcinoma cell lines. The factors affecting the regulation of MCT8 expression at a molecular level in normal physiology, and in syndromes of malplacentation such as IUGR, are as yet unknown and are the subject of further investigation.

\section{Acknowledgements}

We thank Dr David Somerset for aiding with collection of the placental samples, and Dr Kristien Boelaert and Dr Stivelia Kachilele for their help with RNA and RT preparations. 


\section{Funding}

The major sources of funding for this study were the Medical Research Council (UK), Research Committee of the University Hospital Birmingham (UHB) Charity and the Mason Medical Research Foundation. The authors declare that there is no conflict of interest that would prejudice the impartiality of this scientific work.

\section{References}

Abe T, Suzuki T, Unno M, Tokui T \& Ito S 2002 Thyroid hormone transporters: recent advances. Trends in Endocrinology and Metabolism $13215-220$.

Bacon BJ, Gilbert RD \& Longo LD 1986 Regional anatomy of the term human-placenta. Placenta 7 233-241.

Barber KJ, Franklyn JA, McCabe CJ, Khanim FL, Bulmer JN, Whitley GSJ \& Kilby MD 2005 The in vitro effects of triiodothyronine on epidermal growth factor-induced trophoblast function. Journal of Clinical Endocrinology and Metabolism $901655-1661$.

Boelaert K, Tannahill LA, Bulmer JN, Kachilele S, Chan SY, Kim D, Gittoes NJ, Franklyn JA, Kilby MD \& McCabe CJ 2003 A potential role for PTTG/securin in the developing human fetal brain. FASEB Journal 17 1631-1639.

Boelaert K, Yu R, Tannahill L, Stratford AL, Khanim FL, Eggo MC, Moore JS, Young LS, Gittoes N, Franklyn J et al. 2004 PTTG's C-terminal PXXP motifs modulate critical cellular processes in vitro. Journal of Molecular Endocrinology 33 663-677.

Chan S \& Kilby MD 2000 Thyroid hormone and central nervous system development. Journal of Endocrinology 165 1-8.

Chan S, Kachilele S, McCabe C, Tannahill L, Boelaert K, Gittoes N, Visser T, Franklyn J \& Kilby M 2002 Early expression of thyroid hormone deiodinases and receptors in human fetal cerebral cortex. Brain Research Developmental Brain Research 138 109-116.

Chan S, Kachilele S, Hobbs E, Bulmer JN, Boelaert K, McCabe CJ, Driver PM, Bradwell AR, Kester M, Visser TJ et al. 2003 Placental iodothyronine deiodinase expression in normal and growth-restricted human pregnancies. Journal of Clinical Endocrinology and Metabolism 88 4488-4495.

Dumitrescu AM, Liao XH, Best TB, Brockmann K \& Refetoff S 2004 A novel syndrome combining thyroid and neurological abnormalities is associated with mutations in a monocarboxylate transporter gene. American Journal of Human Genetics 74 168-175.

Ekins R 1992 The free hormone hypothesis and measurement of free hormones. Clinical Chemistry 38 1289-1293.

Friesema EC, Ganguly S, Abdalla A, Manning Fox JE, Halestrap AP \& Visser TJ 2003 Identification of monocarboxylate transporter 8 as a specific thyroid hormone transporter. Journal of Biological Chemistry 278 40128-40135.

Friesema ECH, Grueters A, Biebermann H, Krude H, von Moers A, Reeser M, Barrett TG, Mancilla EE, Svensson J, Kester MHA et al. 2004 Association between mutations in a thyroid hormone transporter and severe X-linked psychomotor retardation. Lancet $3641435-1437$.

Gaffney G, Sellers S, Flavell V, Squier M \& Johnson A 1994 Case-control study of intrapartum care, cerebral palsy, and perinatal death. British Medical Journal 308 743-750.

Haddow JE, Palomaki GE, Allan WC, Williams JR, Knight GJ, Gagnon J, O'Heir CE, Mitchell ML, Hermos RJ, Waisbren SE et al 1999 Maternal thyroid deficiency during pregnancy and subsequent neuropsychological development of the child. New England Journal of Medicine 341 549-555.
Hennemann G, Docter R, Friesema EC, de Jong M, Krenning EP \& Visser TJ 2001 Plasma membrane transport of thyroid hormones and its role in thyroid hormone metabolism and bioavailability. Endocrine Reviews 22 451-476.

Hern WM 1984 Correlation of fetal age and measurements between 10 and 26 weeks of gestation. Obstetics and Gynecology 63 26-32.

Hernandez A \& St Germain DL 2003 Thyroid hormone deiodinases: physiology and clinical disorders. Current Opinion in Pediatrics 15 416-420.

Kilby MD 2003 Thyroid hormones and fetal brain development. Clinical Endocrinology 59 280-281.

Kilby MD, Verhaeg J, Gittoes N, Somerset DA, Clark PM \& Franklyn JA 1998 Circulating thyroid hormone concentrations and placental thyroid hormone receptor expression in normal human pregnancy and pregnancy complicated by intrauterine growth restriction (IUGR). Journal of Clinical Endocrinology and Metabolism $832964-2971$.

Koopdonk-Kool JM, de Vijlder JJ, Veenboer GJ, Ris-Stalpers C, Kok JH, Vulsma T, Boer K \& Visser TJ 1996 Type II and type III deiodinase activity in human placenta as a function of gestational age. Journal of Clinical Endocrinology and Metabolism 81 2154-2158.

Lafreniere RG, Carrel L \& Willard HF 1994 A novel transmembrane transporter encoded by the Xpct Gene in Xq13.2. Human Molecular Genetics 3 1133-1139.

Laoag-Fernandez JB, Matsuo H, Murakoshi H, Hamada AL, Tsang BK \& Maruo T 2004 3,5,3'-Triiodothyronine down-regulates Fas and Fas ligand expression and suppresses caspase- 3 and poly (adenosine $5^{6}$-diphosphate-ribose) polymerase cleavage and apoptosis in early placental extravillous trophoblasts in vitro. Journal of Clinical Endocrinology and Metabolism 89 4069-4077.

Oki N, Matsuo H, Nakago S, Murakoshi H, Laoag-Fernandez JB \& Maruo T 2004 Effects of 3,5,3 '-triiodothyronine on the invasive potential and the expression of integrins and matrix metalloproteinases in cultured early placental extravillous trophoblasts. Journal of Clinical Endocrinology and Metabolism 89 5213-5221.

Pop VJ, Kuijpens JL, van Baar AL, Verkerk G, van Son MM, de Vijlder JJ, Vulsma T, Wiersinga WM, Drexhage HA \& Vader HL 1999 Low maternal free thyroxine concentrations during early pregnancy are associated with impaired psychomotor development in infancy. Clinical Endocrinology (Oxford) 50 149-155.

Pop VJ, Brouwers EP, Vader HL, Vulsma T, van Baar AL \& de Vijlder JJ 2003 Maternal hypothyroxinaemia during early pregnancy and subsequent child development: a 3-year follow-up study. Clinical Endocrinology (Oxford) 59 282-288.

Robson SC, Simpson H, Ball E, Lyall F \& Bulmer JN 2002 Punch biopsy of the human placental bed. American Journal of Obstetrics and Gynecology 187 1349-1355.

Schwartz HL 1983 Effects of thyroid hormones in growth and development. In Molecular Basis for Thyroid Action, pp 413-444. Eds JH Oppenheimer \& HH Samuels. NY, USA: Academic Press.

Stanley EL, Hume R, Visser TJ \& Coughtrie MWH 2001 Differential expression of sulfotransferase enzymes involved in thyroid hormone metabolism during human placental development. Journal of Clinical Endocrinology and Metabolism 86 5944-5955.

Thorpe-Beeston JG, Nicolaides KH, Snijders RJ, Felton CV \& McGregor AM 1991 Thyroid function in small for gestational age fetuses. Obstetics and Gynecology 77 701-706.

Vulsma T, Gons MH \& de Vijlder JJ 1989 Maternal-fetal transfer of thyroxine in congenital hypothyroidism due to a total organification defect or thyroid agenesis. New England Journal of Medicine 321 13-16.

Received in final form 1 March 2006

Accepted 16 March 2006

Made available online as an Accepted Preprint 31 March 2006 